Asian Review of Social Sciences

ISSN: 2249-6319 Vol.8 No.2, 2019, pp. 71-77

(C) The Research Publication, www.trp.org.in

\title{
Gender Stereotypes in Occupational Pattern
}

\author{
Neha Verma \\ Assistant Professor, Department of Economics, Kirori Mal College, University of Delhi, New Delhi, India \\ E-Mail: nverma.kmc@gmail.com
}

\begin{abstract}
The paper hypothesizes to examine the 'Exclusion' phenomenon for women workers in Indian labour market through gendered occupational segregation and 'Inclusion' of women in low productivity and low skilled jobs as a result of adverse incorporation based on stereotypes and discriminatory practices prevalent in the society. The gendered division of work space in Indian economy is evident from the disaggregated study of occupational employment patterns and relative educational qualification of employed men and women. The National Sample Survey (NSS) EmploymentUnemployment unit level data $\left(6^{\text {th }}\right.$ Round, 2011-12) is used for the analysis. It is observed that women employment in low productivity jobs is partially a result of their low education level as compared to men workers. However, this is only a part of the answer and the circle of low productivity jobs and low education levels of women is nurtured by the stereotypical foundations of the patriarchal system.

Keywords: Gender Stereotypes, Occupational Segregation, Indian Labour Market, Gender Discrimination in Labour Market
\end{abstract}

\section{INTRODUCTION}

The low labour force participation rate (LFPR) of women in Indian economy is in policy discourse in light of substantial economic growth, strong fertility decline and rising women education (Sarkar et al., 2017). While fertility level has been declining and approaching international norms for India's level of development, LFPR of women in India is considerably behind the international norm of 60 percent (Bhalla \& Kaur, 2011). According to National Sample Survey Office, Indian women's LFPR declined by nearly 7 percent to 22.5 per cent between 2004-05 and 2011-12, even though the economy expanded at an annual rate of 8.5 percent in the period (Tyagi \& Dixit, 2015). It is lower than many other emerging economies and has been declining since the mid 2000s (Das et al., 2015). Women employment has direct positive effect on women's empowerment and indirect effect on child's welfare (Sarkar et al., 2017) but economic well being and welfare of women may not improve if they are engaged in low paying distress driven work (Sharma \& Saha, 2015). Gender gap in employment also reduces economic growth (Klasen \& Lamanna, 2009). There is an increasing role of women in the economic activity (Sharma \& Saha, 2015) along with low LFPR, which raises questions on the nature of work that women undertake and increasing informalisation of women's work (Batra \& G.Reio Jr., 2016).

India has leapfrogged from being an agrarian economy to a services-led economy and services sector has emerged as a boon for women employment. However, there is a duality in service sector in terms of informality and wage inequality, much higher than that in manufacturing sector (Ramaswamy \& Agrawal, 2012). Manufacturing sector has a much greater capacity to absorb labour with lower levels of education as compared to service sector. At the same time, there is a crucial role played by stereotypes in determining the job entry and mobility for women workers in every sector. Gender stereo typing of women work worldwide has created a phenomenon of 'inclusion' of women in their stereotypical job structures and 'exclusion' from traditionally men jobs.

The present study delves into the gendered division of work space in Indian economy through study of occupational employment patterns and relative educational qualification of employed men and women. The paper is divided into six sections including introduction. Section II discusses the related literature on the said topic. Section III presents the research question, data and methodology while Section IV presents the results. Section $\mathrm{V}$ is discussion of the results and emerging perspectives and the Section VI presents policy measures.

\section{RELATED LITERATURE}

Stereotypes of gender roles are defined as a cultural and social approach towards the very thing that is traditionally considered being masculine and feminine roles and functions (Kiaušienè et al., 2011). Women are sidelined from jobs based on prejudices and stereotypes, thereby reinforcing the occupational structure which is bound by gender role expectations (Cassidy \& Warren, 1991). Masculinity is used to denote rationalism, physical power, critical thinking and self confidence, whereas femininity denotes weakness, dependency, emotionality and obedience. This mindset undervalues the women work and men and women are spread over in different occupational and professional groups with less responsible and lower qualification work being delegated to women (Kiaušienè $e t$ al., 2011). These gender stereotypes are reinforced in the labour market and lead to gendered occupational segregation (Verma et al., 2017). This segregation practice originates from endorsement of prejudices, social beliefs and stereotypes about women's inability to perform certain tasks. It is termed as 'trust in (in) ability' by an empirical study, which directly or indirectly affects women's access to education and jobs (Kulkarni \& Hatekar, 2013). There are differences in the work profile of men and women because 
the employers depend upon the social conventions to judge the abilities of women (Verma, 2015) and lesser weight is accorded to her professional qualifications (Kulkarni \& Hatekar, 2013).

The segregation of occupations based on gender does not see the women's career having a consistent orientation towards achievements in the hierarchy of professions (Kiaušienè et al., 2011). The segregation could be horizontal (men and women occupy different professional groups) or vertical (under same occupation, women are allotted less responsible and low qualification work). The socially constructed men domination supports the idea of men's work being more contributory and beneficial than women's work, leading to widely divergent payoffs and social values attached to these professions (Kulkarni \& Hatekar, 2013) encouraging societal and workforce norm of gender inequality (Batra \& G.Reio Jr., 2016). Apart from gender segregation at occupational level, the jobs are also gendered in ways that result in discrimination against women on the basis of employment and wage returns (Rustagi, 2007). A study by International Institute of Labour Studies (2004) finds that since most Indian women are engaged in part-time and informal work under nonunionized labour, it is highly likely that they are employed in low quality work (Sharma \& Saha, 2015). A study based on United States service sector over 1950 to 1990 finds disappearance of men in unskilled jobs and education has not helped women in breaking the barrier of entry and mobility in traditionally men jobs (Steiger \& Wardell, 1995). In the Indian economy, the share of women has been observed to be higher for occupations like Secretaries, Clerks and Operators as opposed to Administrative, Executive and Managerial occupations (Verma et al., 2017).

\section{RESEARCH QUESTION, DATA \& METHODOLOGY}

The present study hypothesizes to examine the 'Exclusion' phenomenon for women workers in Indian labour market through gendered occupational segregation and 'Inclusion' of women in low productivity and low skilled jobs as a result of adverse incorporation based on stereotypes and discriminatory practices prevalent in the society. The paper attempts a three step analysis of women inclusion and exclusion in different occupations in the Indian labour force. The first step examines the differences in the percentage of men and women employed in different occupational divisions recognized under National Classification of Occupations (NCO) -2004. Thereafter, a decomposition analysis is done to assess the segregated occupational patterns in these groupings. For the purpose, Duncan and Duncan Index for Segregation are used to calculate the index of dissimilarity (ID) in the occupational distribution. This analysis finds evidence of stark segregation in Indian labour force based on stereotyping of certain occupations for women even though similar percentage of men and women are employed in the broad divisions of these occupations. The final step is to analyze the educational qualifications of employed men and women to assess the productivity factor of women's work. Education is a strong determinant of high quality work for employed women (Srivastava \& Srivastava, 2009). Therefore, educational qualification of employed men and women in a particular occupation is used as an indicator of the productivity and skill level of their job under the broad category of that occupation. The segregation of work is not only leading to strengthening of societal stereotypes concerning women work but women are sidelined into unskilled and low skilled work under each occupation which does not require much educational level whereas men occupy a skilled job under the same occupation.

The National Sample Survey (NSS) $-68^{\text {th }}$ Round, Employment - Unemployment data (2011-12) is used to study the embedded gender stereotypes in the occupational patterns evident in Indian labour force. NSS Surveys are primary source of data on various labour force indicators at national and state levels. The number of households surveyed in $68^{\text {th }}$ Round was 1,01,724 (59,700 households in rural areas and 42,024 in urban areas). The number of persons surveyed was 4,56,999. The labour force participation, in the paper, is measured through usual principal status signifying the activity on which a person spent relatively longer time during the 365 days preceding the date of survey. The National Classification of Occupations (NCO) - 2004 is used for categorization of different occupations. There are a total of ten divisions under NCO-2004, stated below along with their skill level.

1. Legislators, Senior Officials and Managers (Skill level not defined)

2. Professionals (Skill level - IV)

3. Associate Professionals (Skill level - III)

4. Clerks (Skill level - II)

5. Service Workers and Shop \& Marker Sales Workers (Skill level - II)

6. Skilled Agricultural and Fishery Workers (Skill level II)

7. Craft and Related Trades Workers (Skill level - II)

8. Plant and Machine Operators and Assemblers (Skill level - II)

9. Elementary Occupations (Skill level - I)

10. Workers not classified by Occupations

The broad divisions are further categorized into 114 threedigit level occupations. Under each three-digit level occupation, a job hierarchy is implicitly evident from the differing levels of educational qualification (thereby productivity) of employed men and women.

\section{RESULTS}

\section{A. Labour Force Participation Rate of Women}

The labour force participation rates of men and women have a wide gap as evident from Figure I below. The participation of women is dismal across both sectors (rural 
and urban); however, urban participation is even lower than rural participation. The trend signifies the over representation of women in the agricultural and primary sector activities prevalent in rural economy. These activities require none or low levels of skills and are less productive and remunerative. Overtime, the gap between urban and rural labour force participation rate for women has narrowed down largely driven by fall in participation rates in rural economy but the gender gap is growing overtime (Das, Jain-Chandra, Kochhar, \& Kumar, 2015).

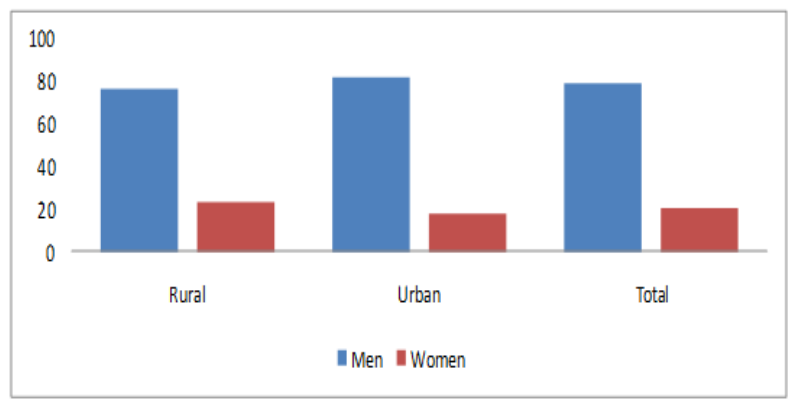

Source: Author's Calculations using NSS $68^{\text {th }}$ Round Survey Data

Fig. 1 Labour Force Participation Rate for Men and Women (2011-12)

The labour force participation according to educational qualifications of men and women is presented in fig. 2 below for both sectors and in total in order to check the phenomenon of U-shaped relationship between education and labour force participation rates of women. The returns to education for men lead to their higher labour force participation. However, this trend is not evident with rising educational qualifications of women. The LFPR for women starts falling as education level increases and then starts to rise among highly educated women who are particularly pulled towards white-collar jobs (there is a sharp increase at LFPR at diploma/ certificate course level). There is a gender gap in education attainment in India and this U-shaped trend for women education further aggravates the problem for their low LFPR.

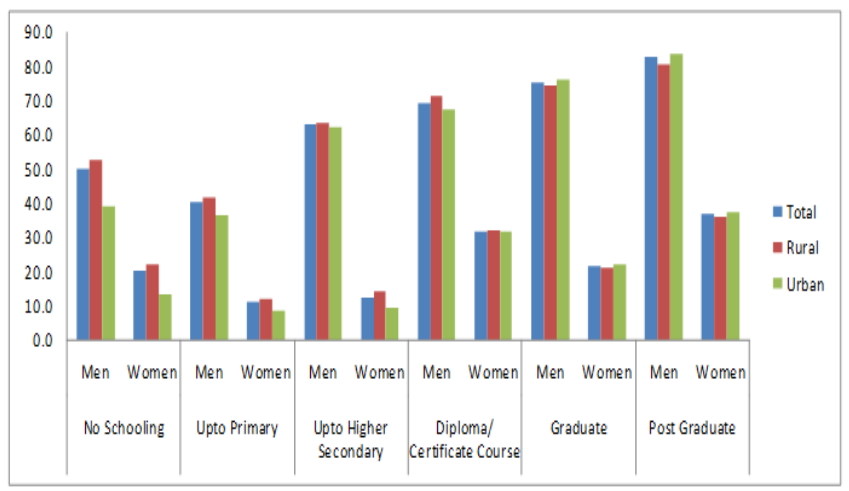

Source: Author's Calculations using NSS $68^{\text {th }}$ Round Survey Data Fig. 2 Labour Force Participation Rate according to Educational Qualifications (2011-12)

\section{B. Employment Pattern in Occupational Divisions}

A high percentage of men and women are employed in 'Skilled Agricultural and Fishery Workers' and 'Elementary
Occupations' which reveals an overall low skill employment for men and women. A relatively higher proportion of women are employed in these occupations as opposed to their men counterparts. The occupation division 'Technicians and Associate Professionals' with a high skill level of III shows a higher participation by women as compared to men. On the other hand, in the category of 'Legislators, Senior Officials \& Managers' a lesser percentage of women are employed relative to men. An equal percentage of men and women are employed as 'Professionals'. For the other divisions, a higher proportion of men is employed vis-à-vis women.

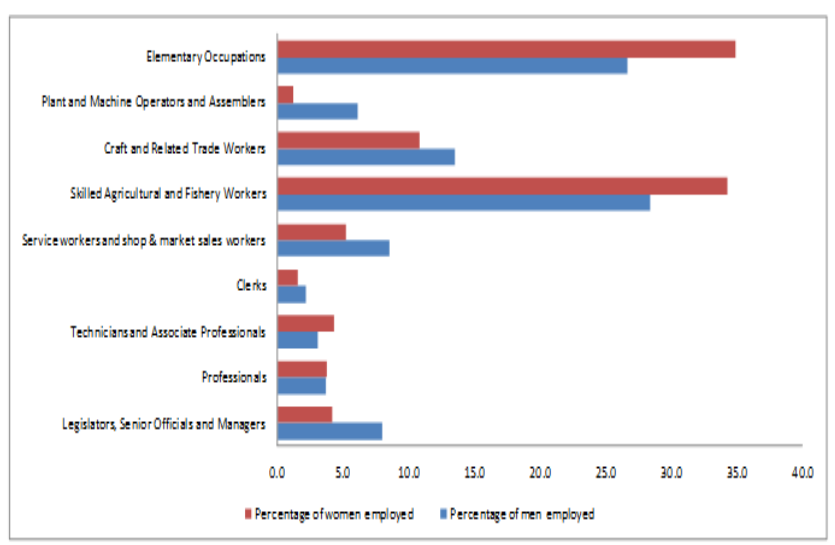

Source: Author's Calculations using NSS $68^{\text {th }}$ Round Survey Data Fig. 3 Percentage of Men \& Women Employed in Occupational Divisions (2011-12)

The fig. 3 data shows the overall low skill level of workers in India with higher proportion of both men and women being employed in low skill level occupational divisions. A disaggregated analysis presented below reveals that women are employed in even lower productivity jobs under the low skill occupational divisions.

\section{Decomposition Analysis of Employment in Three-Digit Level Occupations}

Each of the divisions under NCO-2004 is further divided into three-digit level occupations. For the purpose of analysis, Duncan and Duncan Index of Segregation (ID) are calculated for each division to see if men and women are employed in different types of three-digit occupations.

$$
\mathrm{ID}=\frac{\Sigma_{\mathrm{v}}^{\mathrm{v}} \mid M_{\mathrm{i}} \mathrm{M}^{-F_{\mathrm{i}_{F}} \mid}}{2}
$$

$\mathrm{M} i$ (Fi) is the number of men (women) employed in occupation ' $i$ ' and $\mathrm{M}(\mathrm{F})$ is the total number of men (women) employed in the service sector industrial group. If the total number of occupations in a single industrial group is $n$, then the ID for that group is calculated as shown in equation (1). The index expressed as a percentage, can be loosely interpreted as the proportion of women (or men) that would have to change occupations for the occupational distribution of to be same across gender. A value of 0 percent indicates that the distribution of women across 
occupations is the same as that of men, while a value of 100 percent indicates that women and men work in completely different occupations.

The highest level of segregation (60.5 percent) is evident in division 'Plant and Machine Operators and Assemblers' (see figure IV below) which implies that for occupational division to be equal among men and women here, 60.5 percent of men or women would have to change their occupations under this division. Here, men are majorly employed as Motor Vehicles Drivers (52.2 percent of men in this division as opposed to 1.8 per cent of women) while women are employed as Chemical Products Machine Operators (10.9 percent of women in this division as opposed to 1.5 percent of men) and Textile, Fur and Leather Products Machine Operators (39.4 percent of women in this division as opposed to 8.6 percent of men). A skill level III division 'Technicians and Associate Professionals' (where proportion of women employed is greater than that of men as shown in fig.3) also has high degree of segregation (50.8 percent). Women are employed in stereotypical roles of care givers and teaching like Nursing and Midwifery Associates (15.7 percent of women in this division as opposed to 2 percent of men), Middle, Primary and Pre-Primary Education Teaching Associate Professionals (62 percent of women in this division as opposed to 26 percent of men), while men are over represented in relatively high skilled, intellectually demanding and more remunerative occupations of Physical and Engineering Science Technicians, Finance, Sales and Administrative Associate Professionals. In the division 'Craft and Related Trades Workers', gendered occupational segregation reveals that women are overrepresented in Food Processing, Textiles and Garments Trades (66 percent of women in this division as opposed to 19 percent of men).

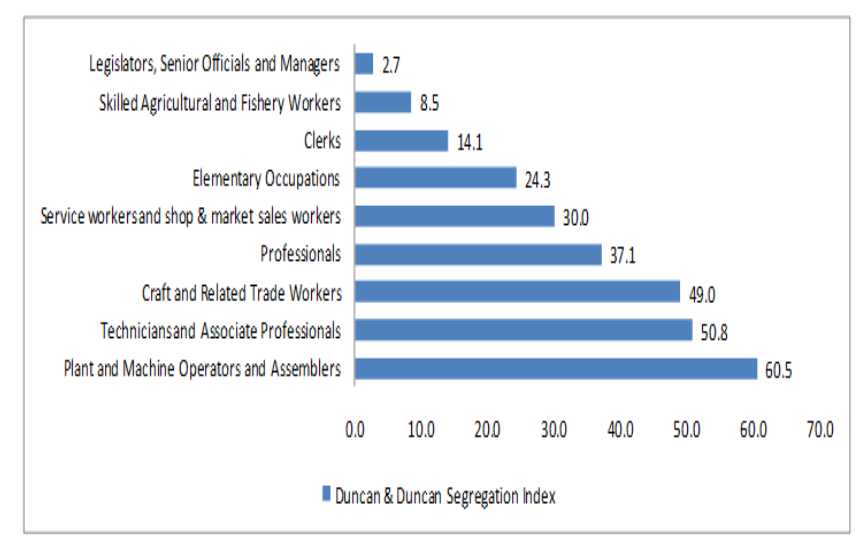

Source: Author's Calculations using NSS $68^{\text {th }}$ Round Survey Data

Fig. 4 Duncan \& Duncan Segregation Index (2011-12)

Though almost equal percentage of men and women work as 'Professionals' (see Fig.1), but the decomposition analysis based on segregation indices reveal that men and women work in differentiated occupations under this division. Women are majorly hired as Nursing Professionals, College, University and Higher Education Teaching, Secondary Education Teaching Professionals and Other Teaching Professionals. Men are predominately employed as Architects, Engineers and Related Professionals, Business, Legal and Religious Professionals. There is a clear demarcation of work space for women wherein they are pushed in conventionally stereotyped roles of being care giver or teacher. Under 'Service Workers', women are predominately employed in House Keeping and Restaurant Service Workers and Personal Care and Related Workers (44 percent of women in this division as opposed to 14 percent of men).

A more contrasting picture emerges in the divisions of 'Elementary Occupations' wherein women are sidelined into occupations of Domestic and Related Helpers, Cleaners and Launderers (8.9 percent of total women employed in this division) whereas only 1.8 percent of men employed in this division are part of these occupations. Around 75 percent of women employed in 'Elementary Occupations' are employed as Agricultural, Fishery and Related Laborers as opposed to 58 percent of such men. Men, under this division are majorly employed as Mining and Construction Workers. A subsector wise analysis of the division 'Legislators, Senior Officials \& Managers' reveals that a higher percentage of men are participating in managerial level positions like Production and Operations Department Managers. Among the sub-sectors of 'Skilled Agricultural and Fishery Workers', women are majorly employed as Market Gardeners and Crop-growers, Market Oriented Animal Producers and Subsistence Agricultural and Fishery Workers.

\section{Educational Qualification of Working Population}

The study of gender based labour market occupational pattern is incomplete and non credible without analysis of educational levels of men and women as low educational level is often cited as a reason for exclusion of women workers from high productivity and skill jobs. The fig. 5 below depicts the overall low educational attainment of working population in the country with almost 50 percent of women are in the category of 'No Schooling' and 40 percent of men are only educated 'Up to Higher Secondary'. This justifies the trend observed in fig. 3 that Indian working population is majorly employed in low skilled category of occupations.

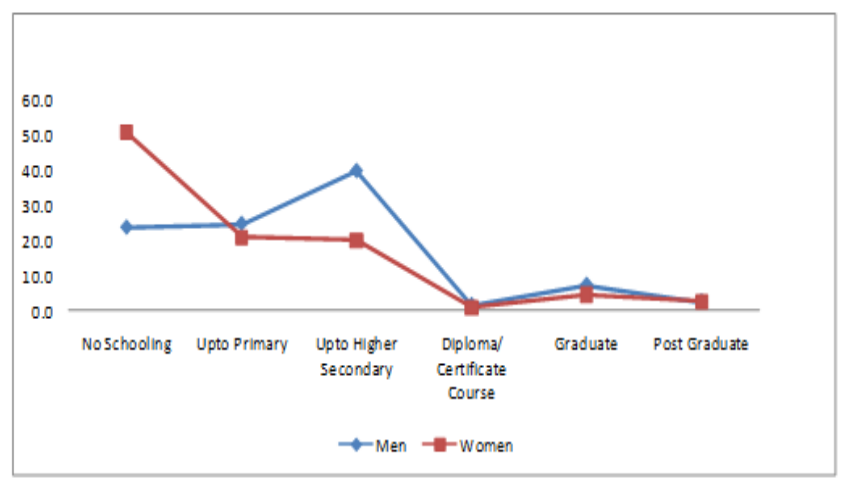

Source: Author's Calculations using NSS $68^{\text {th }}$ Round Survey Data Fig. 5 Educational Qualification of Working Population (2011-12) 
The analysis of the educational qualification of employed men and women according to occupational divisions reveals that for every occupation division, percentage of employed women with no schooling is greater than that for employed men which clearly indicates the inclusion of women into low skill jobs under these occupations and exclusion from high skilled or high paying occupations which require higher educational qualification. No such stark differentiation is observed in the percentage of men and women with post graduation.

\section{DISCUSSION}

The labour force participation of women in India has been much below the international norm of 60 percent. The issues relating to women's work employment are qualitatively different from those of men workers (Beneria $\&$ Sen, 1981). The lower participation rate of women can be largely driven by the substantial wage gap discrimination based on gender in India, wherein Indian women systematically earn less than their men counterparts. The lower wages of women are primarily because of low education levels of women and lesser experience than men (Bhalla \& Kaur, 2011). The discrimination against women emanates from her birth and gender stereotyping of work restricts women's study and career choices and unequal allocation of education resources between daughters and sons in the households always holds her back in a competitive scenario. Moreover, child bearing and rearing requires her to withdraw from the labour force which reduces her experience vis-à-vis men. These factors, along with seclusion of upper class and caste women from the labour force to maintain high family status lead to lower participation by women. The stereotyping of work is evident in the results presented above. The domestic responsibilities get extended to labour market contexts and most common jobs for women become that of personal service providers like maids, cooks, tailors and nurses. Moreover, social convention of teaching being an apt job for working women is an extension of her parenting and caring role at home towards her children. It is worth noting that teaching at higher education levels have lesser percentage of women vis-à-vis men, again indicative of stereotyping towards her productivity and skill level.

These factors point to the phenomenon of social exclusion being operative in India wherein various institutional mechanisms systematically deny certain groups of people (women in this case) the access to resources and recognition which will allow them to participate fully in that sector or society (Kabeer, 2000). Women are systematically stereotyped in certain occupations under the garb of low educational qualifications, less experience and upward mobility strategies of upper castes and classes. The phenomenon of social exclusion could be based on economic disadvantage or cultural factors operative in the society (Deshpande, 2012). A wage gap between men and women can also lower women participation level in the workforce (Bhalla \& Kaur, 2011); along with other factors like increase in the wealth as well as income of other members of the household which lowers the entry and increases the exit probabilities for women from the labour force (Sarkar et al., 2017).

A major finding in employment patterns of women is the stubborn domination of agriculture as the primary source of work for women. The concern emanates from the persistent agrarian crisis which makes involvement in such work increasingly fraught and financially unviable. During 201112, more than 35 percent of rural women were casually employed while this figure stood at less than 15 percent for urban women (Sharma \& Saha, 2015). This indicates that most rural women work long hours in poor working conditions and low earning opportunities. It also implies that the services led growth of India has been unable to internalize the women workforce in formal service sector employment. On the other hand, women employed in public sector provision of services are concentrated in low remunerative activities with uncertain contracts and hardly any benefits like school education, health and nutrition workers (Ghosh, 2004).

A closer discussion on the impact of gender stereotyping of work on women's employment and future career prospects reveals that segregationist framework gets reinforced by such stereotyping which eventually leads to even stronger segregation. This social construct give rise to vicious circle for women of stereotyping of their abilities, assignment of low productivity jobs, less investment in their education and training and even further stereotyping of their abilities. If the process of assigning relatively unskilled jobs to women continues overtime, then these women develop a certain level of skill in these unskilled jobs as they do it daily. Then these jobs automatically get segmented by the employer and the employee, leading to an equilibrium situation (Chakraborty, 2013). In case of horizontal segregation, the decision making roles are allocated primarily to men (like Chief Executive Officers, Department Managers, Administrative and Executive Officials) who results the decisions being an expression and cause of further gender segregation and inequality (Batra \& G.Reio Jr., 2016).

The present paper examines the differing educational qualification between employed men and women across three-digit level occupations as lack of education is often cited as a reason for low LFPR of women in India. It is fairly well established by econometric studies that returns to education by levels of education in India have been increasing in recent years (Agarwal, 2011). However, such returns are not accruing to women according to present study as almost 50 percent of employed women fall in the category of 'No Schooling'. General education levels of all persons in the country have been improving overtime, but women are registering a higher rate of increase (Rustagi, 2010). But this improvement is not reflected in the educational qualification of the working women. 
Women in urban India, though educated are opting out of full time employment. It is found that only 22 percent of educated urban women entered the workforce in the 201112 (Madhok, 2014). In urban areas, women participation rate is higher for illiterate women than for women with higher levels of education except graduates (Unni \& Rani, 2000). The women with low education level work out of need and women with high education level are often secluded from the labour market on account of family honor and high wealth and income quintile of the family.

The study of entry and exit pattern of women from the labour market finds that presence of an spouse (man) with higher levels of education significantly discourages women to enter the labour force (Sarkar et al., 2017) and has a larger negative effect (each extra year of man's education means a drop in female participation of one percentage point) than the positive effect on women LFPR of increasing women education (Bhalla \& Kaur, 2011). Educating a man, therefore, not only affects woman's education through unequal intra-household resource allocation but also inhibits women from working in her later life. Women employment in low productivity jobs is partially a result of their low education level as compared to men workers. However, this is only a part of the answer and the circle of low productivity jobs and low education levels of women is nurtured by the stereotypical foundations of the patriarchal system.

\section{CONCLUSION \& POLICY MEASURES}

To conclude, the gender stereotypes are deeply embedded in the patriarchal society and have their manifestations in the education and job market which affect women's LFPR negatively. The women workforce face the 'double bind' of being excluded from high skill and remunerative occupations and being included in low skilled and less productive activities of the economy. The current education level of working women is too low as majority of them have not attended formal schooling. Men fare better than women in participation rate, education level and skill enhancing job profiles. Based on the discussion of gendered segregation of work wherein there is 'Inclusion' of women in low productivity work and 'Exclusion' from high skilled and remunerative work, following policy measures can be suggested.

First, the recruitment and training processes should be made gender-neutral. The organizations (through the Human Resource Department) must systematically break down the barriers inhibiting equal participation of women in the workforce. This can be achieved by correcting the gendered division of labour in recruitment, selection and training departments which feeds into the process of amplifying this segregation. The increasing women representation in these departments will increase their bargaining power in the organization (Batra \& G.Reio Jr., 2016).
Second, the major obstacle in women's career path is the maternity and child care period which significantly reduces her experience as compared to men and puts her behind in the professional hierarchy. The need is for sensitivity towards women child caring roles and do not shun them from the economic mainstream activities because of inevitable break in their career due to such role. A study finds that if one accounted for the loss of experience due to child rearing, then, given their human capital background, women obtained a similar wage as men in United States (O'Neill, 2003). Social provision for a significant part of household unpaid work of women or changes in the gendered division of work in the household can also enhance the employability of women.

Third, the education level of women needs to be increased in order for them to break through the glass ceiling and emerge in high skill/ productivity jobs. The results presented also suggest that diploma/certificate course can increase the LFPR of women by a large extent (see fig.2). Therefore, focus on specialized and vocational training can also generate positive results. With the introduction of Right to Education Act, 2009 and 'Sarva Shiksha Abhiyan', there has been improvement in the basic education level up to 14 years of age but mean years of education after 14 years is 2.1 years for rural women and 3.4 years for urban women (Sanghi, Srija, \& Vijay, 2015). Therefore, for employability, the enhancement of skills after 14 years of age is a prerequisite. There is underrepresentation of women in scientific and engineering fields (Kulkarni \& Hatekar, 2013) which need to be corrected.

Fourth, given that a bulk of women are employed in primary sector activities, attention to the issues of enhancing productivities and returns in the agricultural sector is important. Fifth, the norms and stereotypes around womanhood are only half of the problem and the other half is the embedded patriarchal mindset which creates stereotypes around manhood too. These perceptions collectively normalize the idea that men should have control over woman's choices and mobility which largely prevent men from taking an equal share in traditionally women work, whether in labour market or in household. This perception need to be altered through gender neutral socialization and correction of society's poor expectations from women.

\section{REFERENCES}

[1] Agarwal, T. (2011). Returns to Education in India: Some Recent Evidence. Mumbai: Indira Gandhi Institute of Development Research Working Papers.

[2] Batra, R., \& G.Reio Jr., T. (2016). Gender Inequality Issues in India. Advances in Developing Human Resources , 18(1), 88-101.

[3] Beneria, L., \& Sen, G. (1981). Accumulation, Reproduction, and "Women's Role in Economic Development": Boserup Revisited. Signs , 7(2), 279-298.

[4] Bhalla, S. A., \& Kaur, R. (2011). Labour Force Participation of Women in India: Some facts, some queries. London: LSE Asia Research Centre, Working Paper. 
[5] Cassidy, M. L., \& Warren, B. O. (1991). Status Consistency and Work Satisfaction among Professional and Managerial Women and Men. Gender and Society, 5(2), 193-206.

[6] Chakraborty, S. (2013). Occupational Gender Segregation in India. Researchjournali's Journal of Economics , 1(2).

[7] Das, S., Jain-Chandra, S., Kochhar, K., \& Kumar, N. (2015). Women Workers in India: Why So Few Among So Many? International Monetary Fund, Working Paper.

[8] Deshpande, A. (2012). Exclusion and Inclusive Growth. United Nations Development Programme.

[9] Ghosh, J. (2004). Informalisation and Women's Workforce Participation: A Consideration of Recent Trends in Asia. In Featured Articles International Development economics Associates .

[10] Kabeer, N. (2000). Social Exclusion, Poverty and Discrimination: Towards an analytical framework. IDS Bulletin , 31(4), 83-97.

[11] Kiaušienè, I., Štreimikienè, D., \& Grundey, D. (2011). On Gender Stereotyping and Employment Assimetries. Economics and Sociology , 4(2), 84-97.

[12] Klasen, S., \& Lamanna, F. (2009). The Impact of Gender Inequality in Education and Employment on Economic Growth: New Evidence for a Panel of Countries. Feminist Economics , 15(3), 91-132.

[13] Kulkarni, S., \& Hatekar, N. (2013). Stereotypical Occupational Segregation and Gender Inequality: An Experimental Study. Economic and Political Weekly, 48(32), 112-120.

[14] Madhok, D. (n.d.). Missing Women: India's record in women's participation in the workforce is depressing. Retrieved from http://qz.com/238484/indias-record-in-womens-participation-in-theworkforce-is-depressing/

[15] O'Neill, J. (2003). The Gender Gap in Wages, Circa 2000. American Economic Review.

[16] Ramaswamy, K., \& Agrawal, T. (2012). Services-led Growth, Employment and Job Quality: A Study of Manufacturing and Servicesector in Urban India. Mumbai: Indira Gandhi Institute of Development Research.
[17] Rustagi, P. (2010). Continuing Gender Stereotypes or Signs of Change: Occupational Pattern of Women Workers. The Indian Journal of Labour Economics , 53(3), 481-499.

[18] Rustagi, P. (2007). Women and Poverty: Rural-Urban Dimensions. Social Change, 37(4), 1-36.

[19] Sanghi, S., Srija, A., \& Vijay, S. S. (2015). Decline in Rural Female Labour Force Participation in India: A Relook into the causes. The Journal for Decision Makers , 40(3), 255-268.

[20] Sarkar, S., Sahoo, S., \& Klasen, S. (2017). Employment Transitions of Women in India: A panel Analysis. Germany: IZA Institute of Labour Economics, Discussion Paper Series.

[21] Sharma, A., \& Saha, S. (2015). Female Employment Trends in India: A Disaggregated Analysis. The NEHU Journal , 13(2), 17-30.

[22] Srivastava, N., \& Srivastava, R. (2009). Women, Work and Employment Outcomes in Rural India. Discussion Draft presented at FAO-IFAD-ILO Workshop on Gaps, Trends and Current Dimensions in Agricultural and Rural Employment.

[23] Steiger, T. L., \& Wardell, M. (1995). Gender and Employment in the Service Sector. Social Problems, 91-123.

[24] Tyagi, A., \& Dixit, P. (2015). Factors Affecting Declining Female Employment Rate in Service Sector in India-A study conducted in Delhi-NCR. Advances in Economics and Business Management, 672676.

[25] Unni, J., \& Rani, U. (2000). Women in Informal Employment in India. The International Association for Feminist Economics Conference. Istanbul.

[26] Verma, N. (2015). Gender Discrimination in the Boardroom. In P. Kumar (Ed.), Unveiling Women's Leadership: Identity and Meaning of Leadership in India, 75-97. London: Palgrave Macmillan.

[27] Verma, N., Sethi, M. A., \& Parihar, S. (2017). Gendered Occupational Segregation in the Indian Service Sector. In K. Gill, \& K. V. Bhanu Murthy (Eds.), India's Service Sector, Emerging Perspectives, 25-42. Delhi: Athena Academic. 